\title{
A retrospective study of autologous stem cell mobilization by G-CSF in combination with chemotherapy in patients with multiple myeloma and lymphoma
}

\author{
GAOFENG ZHENG, JINGSONG HE, ZHEN CAI, DONGHUA HE, YI LUO, \\ JIMIN SHI, GUOQING WEI, JIE SUN and WEIYAN ZHENG \\ Bone Marrow Transplantation Center, First Affiliated Hospital, Zhejiang University and \\ First Hospital of Zhejiang Province, Hangzhou, Zhejiang 310001, P.R. China
}

Received December 18, 2017; Accepted August 8, 2019

DOI: $10.3892 / \mathrm{ol} .2019 .11177$

\begin{abstract}
Factors affecting peripheral blood hematopoietic stem cell (PBSC) mobilization and collection were investigated in patients with multiple myeloma (MM) and lymphoma who were undergoing chemotherapy. Clinical data from 128 patients, including $53 \mathrm{MM}$ and 75 malignant lymphoma (7 Hodgkin's lymphoma and 68 non-Hodgkin's lymphoma) cases were retrospectively analyzed. Autologous PBSCs were mobilized using granulocyte-colony stimulating factor (G-CSF) during chemotherapy, and collected using a continuous flow cell separation instrument. The yields of CD34+ cells per kilogram of patient body weight $<2.0 \times 10^{6} / \mathrm{kg},>2.0 \times 10^{6} / \mathrm{kg}$ or $>5.0 \times 10^{6} / \mathrm{kg}$ were defined as a failure, a success or ideal mobilization, respectively. In MM and lymphoma patients, the success rates of CD34+ cell acquisition were $73.6(39 / 53)$ and $58.7 \%(44 / 75)$, the ideal rates were $43.4(23 / 53)$ and $30.7 \%(23 / 75)$, and the failure rates were $26.4(14 / 53)$ and $41.3 \%$ (31/75), respectively. Univariate and multivariate statistical analysis revealed that negative factors for PBSC mobilization in patients with MM were lenalidomide treatment, multiple chemotherapies, incomplete disease remission and low-level blood hemoglobin; in patients with lymphoma, the negative factors were the histological disease type, incomplete disease remission, being beyond the first-line of previous chemotherapy, multiple chemotherapies, chemotherapy with the HyperCVAD-B mobilization scheme, high-dose MTX/Ara-c (methotrexate/cytarabine) treatment, prolonged administration of G-CSF and low-hematocrit levels. In the
\end{abstract}

Correspondence to: Dr Jingsong He, Bone Marrow Transplantation Center, First Affiliated Hospital, Zhejiang University and First Hospital of Zhejiang Province, 79 Qingchun Road, Hangzhou, Zhejiang 310001, P.R. China

E-mail: hejingsong@zju.edu.cn

Key words: hematopoietic stem cells, mobilization, separation, collection, influencing factors, multiple myeloma, lymphoma present study, different factors influencing PBSC mobilization and collection in MM and lymphoma cases were identified. PBSC mobilization yielded sufficient CD34+ cell counts both in MM and lymphoma patients; however, the failure rates were relatively high.

\section{Introduction}

High-dose chemotherapy combined with autologous hematopoietic stem cell transplantation (ASCT) has been widely used in the treatment of hematologic malignancies, including multiple myeloma (MM) and a number of different types of lymphoma. This combination therapy has been proven to significantly improve the progression-free survival (PFS) and overall survival (OS) times of patients (1). Although since 2000, a large number of targeted treatments have been used in clinical drug therapy, ASCT still results in the most favorable patient outcome (1-3). Efficient acquisition of autologous stem cells is the premise of successful ASCT. Peripheral blood hematopoietic stem cells (PBSCs) are the stem cell sources for almost all ASCTs. Compared with ASCT with bone marrow hematopoietic cells, it is generally accepted that ASCT with PBSCs requires fewer cells for infusion; additionally, the collection procedure for PBSCs is simpler, and patients recover more quickly, thus resulting in a shorter period of hospitalization. During the PBSC mobilization process, monitoring the mononuclear and CD34+ cell count in the peripheral blood enables the prediction of acquisition efficiency, and helps to determine the timing of acquisition. Hübel et al (3) used peripheral blood CD34+ cells as a routine predictive indicator. However, few studies have reported precise changes in the CD34+ cell count during the mobilization process.

$\mathrm{MM}$ and lymphoma are the major hematologic malignancies treated with ASCT and further studies are required to improve PBSC mobilization, as well as to accurately identify patients at a high risk of mobilization failure. In the present study, in order to identify the factors influencing hematopoietic stem cell mobilization, the clinical data of $128 \mathrm{MM}$ and lymphoma patients who received ASCT were retrospectively analyzed. 


\section{Materials and methods}

Patients. The present study was approved by the ethical committee of the Bone Marrow Transplantation Center of the First Affiliated Hospital, Zhejiang University, and all participants provided written informed consent for participation. The clinical data of MM and lymphoma patients admitted to the center between April 2006 and October 2013 were retrospectively analyzed. All participating patients were recruited following routine clinical examinations, and were suitable for, and agreed to accept ASCT therapy. A total of 128 patients (72 male and 56 female; mean age, 44 years; age range, 16-64 years) were studied. There were 53 cases with MM and 75 cases with lymphoma; 7 of these were Hodgkin's lymphoma (HL) and 68 were non-Hodgkin's lymphoma (NHL) based on the World Health Organization diagnostic criteria (4). Most of the patients accepted PBSC mobilization and collection for the first time, but three patients underwent re-collection after first-time failure.

Treatment schemes and PBSC mobilization protocol. All MM patients were treated with high-dose cyclophosphamide (CTX; $3-4 \mathrm{~g} / \mathrm{m}^{2}$ every two days). Of the 75 patients with lymphoma, 33 patients were treated with chemotherapy adopting the CHOP scheme (cyclophosphamide, epirubicin, vincristine and prednisone), five cases of which were supplemented with rituximab, 20 cases with etoposide, and five cases with rituximab and etoposide; 17 patients were treated with a high-dose of CTX, two cases in which rituximab was additionally included; nine patients underwent chemotherapy adopting the HyperCVAD part A scheme (high-dose cyclophosphamide, doxorubicin, dexamethasone and vincristine); another nine patients received chemotherapy adopting the HyperCVAD part B scheme (high-dose cytosine arabinoside and methotrexate), two cases in which rituximab was additionally included; seven patients were treated with chemotherapy adopting a MINE scheme (mitoxantraone, ifosfamide and etoposide) and three cases in which rituximab was also included.

Prior to stem cell collection, all 128 patients were treated with granulocyte-colony stimulating factor (G-CSF; Kyowa Hakko Kirin China Pharmaceutical Co., Ltd.) at the median dose of $5.10 \mu \mathrm{g} / \mathrm{kg}$ (range, 3.57-8.49) for the median period of 5 days (range, 1-16) by subcutaneous injection. When the peripheral white blood cell count decreased to $1.0-2.0 \times 10^{9} / 1$ after chemotherapy, $300 \mu \mathrm{g}$ /day G-CSF was administered to patients via two consecutive subcutaneous injections. In the case of patients with a weight $>70 \mathrm{~kg}, 450 \mu \mathrm{g} /$ day G-CSF was administered.

Stem cell collection. To collect cells, the COBE Spectra (Terumo BCT. Inc.), continuous flow cell separator was used with a collecting blood flow of 18-20 1. The collected mononuclear and CD34+ cells were counted using a flow cytometer (BD FACSCanto $^{\mathrm{TM}}$ II; BD Biosciences). The efficiency of stem cell mobilization was defined by the number of CD34+ cells and the patient's body weight: $\geq 2.0 \times 10^{6} / \mathrm{kg}$ was a successful mobilization; $<2.0 \times 10^{6} / \mathrm{kg}$ was a mobilization failure; and $>5.0 \times 10^{6} / \mathrm{kg}$ was an ideal mobilization $(5,6)$.In addition, the peripheral blood mononuclear cell (B-MNC) count, the level of hemoglobin $(\mathrm{Hb})$, the hematocrit level (Rct) and the blood platelet (Plt) count were determined in peripheral blood cell samples, using a Sysmex XN-9100 ${ }^{\mathrm{TM}}$ Automated Hematology system (Sysmex Corporation).

Statistical analysis. Continuous data that conform to the normal distribution are presented as the mean \pm standard deviation; continuous data that are not normally distributed are presented as the median (range), and classified data are presented as an actual number (rate). The $\chi^{2}$ test was used for the comparison of rate differences and the Mann-Whitney $\mathrm{U}$ test (two groups) or Kruskal-Wallis test (multi groups) for the comparison of continuous datasets. Multiple regression models were used to analyze factors influencing stem cell mobilization and collection. When univariate analysis produced statistical significance, further multivariate analysis with a stepwise regression model was performed. Statistical analysis was conducted using SPSS (version 17.0; SPSS Inc.), and P $<0.05$ was considered to indicate a statistically significant difference.

\section{Results}

Patient baseline status and PBSC mobilization. Of the 53 patients with MM, the therapeutic outcome of PBSC mobilization treatment was a partial response (PR) in 19 patients, and a complete response (CR) in 34 cases (Table I). In 75 patients with lymphoma, 40 (53.3\%) achieved a CR (Table II).

Parameters of stem cell collection. The patients (113 of 128 cases, $88.3 \%$ ) were subjected to stem cell collection for two consecutive days, while four patients were subjected to collection only once, and 15 patients three times. The first and second acquisition of CD34+ cells represented 54.0 and $42.2 \%$ of the total CD34+ cells collected, respectively. In the cell samples, the peripheral blood mononuclear cell (B-MNC) count was $1.9 \times 10^{9} / 1$ (range, 0.1-8.2), the level of hemoglobin (Hb) was $104.2 \mathrm{~g} / 1$ (range, 66.0-142.0), the hematocrit level (Rct) was 30.8\% (range, 19.5-42.7), and the blood platelet (Plt) count was $88.0 \times 10^{9} / 1$ (range, 19.0-250.0).

Collection of CD34+ cells. The median CD34+ cell count collected from all patients was $3.12 \times 10^{6} / \mathrm{kg}$ (range, 0.03-24.07). The median CD34+ counts in MM and lymphoma patients were $4.16 \times 10^{6} / \mathrm{kg}$ (range, $0.10-19.02$ ) and $2.40 \times 10^{6} / \mathrm{kg}$ (range, 0.03-24.07), respectively. Greater numbers of CD34+ cells were collected from patients with MM compared with patients with lymphoma; however, the difference was not statistically significant $(\mathrm{P}=0.064)$. In addition, $>2.0 \times 10^{6} / \mathrm{kg} \mathrm{CD} 34+$ cells were obtained in 83 of the 128 patients $(64.8 \%)$, and $>5.0 \times 10^{6} / \mathrm{kg}$ cells were successfully collected from 45 patients $(35.2 \%)$. The success rate of CD34+ cell collection was $73.6 \%(39 / 53)$ in patients with MM and $58.7 \%$ (44/75) in patients with lymphoma, and the ideal rates were 43.4 (23/53) and 30.7\% (23/75), respectively (Table I and II). This demonstrates that both the success and ideal rates were greater in patients with MM compared with patients with lymphoma. In 45 patients (35.2\%), including $14 \mathrm{MM}$ and 31 lymphoma cases, mobilization failed.

Stem cell mobilization and univariate/multivariate analysis of stem cell mobilization data. Univariate analysis demonstrated that the success rate of mobilization was lower in 
Table I. Baseline characteristics of MM patients and the outcome of PBSCs mobilization.

\begin{tabular}{|c|c|c|c|c|}
\hline \multirow[b]{2}{*}{ Patient characteristics } & \multirow[b]{2}{*}{ Patients, n (\%) } & \multicolumn{2}{|c|}{ Mobilization, n (\%) } & \multirow[b]{2}{*}{ P-value } \\
\hline & & Success & Failure & \\
\hline Number & $53(100)$ & $39(74)$ & $14(26)$ & \\
\hline Age, years ${ }^{\mathrm{a}}$ & $55(24-64)$ & $55(24-64)$ & $55.5(43-64)$ & 0.424 \\
\hline $\operatorname{Sex}^{\mathrm{b}}$ & & & & 0.832 \\
\hline Male & $29(55)$ & $21(54)$ & $8(57)$ & \\
\hline Female & $24(45)$ & $18(46)$ & $6(43)$ & \\
\hline Status of disease ${ }^{b}$ & & & & 0.524 \\
\hline PR/VGPR & $19(36)$ & $13(33)$ & $6(43)$ & \\
\hline $\mathrm{CR} / \mathrm{nCR}$ & $34(64)$ & $26(67)$ & $8(57)$ & \\
\hline Number of prior lines ${ }^{b}$ & & & & 1.000 \\
\hline 1 & $48(91)$ & $35(90)$ & $13(93)$ & \\
\hline$\geq 2$ & $5(9)$ & $4(10)$ & $1(7)$ & \\
\hline Previous lenalidomide treatment ${ }^{b}$ & & & & 0.004 \\
\hline Yes & $4(8)$ & $0(0)$ & $4(29)$ & \\
\hline No & $49(92)$ & $39(100)$ & $10(71)$ & \\
\hline Previous thalidomide treatment ${ }^{b}$ & & & & 0.919 \\
\hline Yes & $9(17)$ & $6(15)$ & $3(21)$ & \\
\hline No & $44(83)$ & $33(85)$ & $11(79)$ & \\
\hline Previous velcade treatment ${ }^{\mathrm{b}}$ & & & & 0.322 \\
\hline Yes & $41(77)$ & $32(82)$ & $9(64)$ & \\
\hline No & $12(23)$ & $7(18)$ & $5(36)$ & \\
\hline Treatment courses $^{\mathrm{b}}$ & & & & 0.075 \\
\hline $1-4$ & $22(42)$ & $19(49)$ & $3(21)$ & \\
\hline$\geq 5$ & $31(58)$ & $20(51)$ & $11(79)$ & \\
\hline Isolation times $^{\mathrm{b}}$ & & & & 0.755 \\
\hline 2 & $42(79)$ & $30(77)$ & $12(86)$ & \\
\hline$>2$ & $11(21)$ & $9(23)$ & $2(14)$ & \\
\hline G-CSF dosage $(\mu \mathrm{g} / \mathrm{kg})^{\mathrm{a}}$ & $5.0(3.6-7.7)$ & $5.1(3.6-7.7)$ & $5.0(4.0-7.5)$ & 0.531 \\
\hline G-CSF duration (d) ${ }^{\mathrm{a}}$ & & & & 0.682 \\
\hline $1-5$ & $40(75)$ & $30(77)$ & $10(71)$ & \\
\hline$>5$ & $13(25)$ & $9(23)$ & $4(29)$ & \\
\hline \multicolumn{5}{|l|}{ Hematological values } \\
\hline $\mathrm{B}-\mathrm{MNC}\left(\times 10^{9} / 1\right)^{\mathrm{a}}$ & $2.1(0.3-8.2)$ & $2.2(0.4-8.2)$ & $1.8(0.3-4.3)$ & 0.143 \\
\hline $\mathrm{Hb}(\mathrm{g} / \mathrm{l})^{1}$ & $111(66.3-142)$ & $112.2(74-142)$ & $103.7(66.3-122)$ & 0.083 \\
\hline $\operatorname{Rct}(\%)^{1}$ & $33(20.1-42.7)$ & $33.2(21.8-42.7)$ & $31.4(20.1-38.2)$ & 0.125 \\
\hline Plt $\left(\times 10^{9} / 1\right)^{1}$ & $90(26.3-238.5)$ & $90(26.3-238.5)$ & $89.5(45-173)$ & 0.896 \\
\hline
\end{tabular}

${ }^{a}$ Mann-Whitney U test; ${ }^{b} \chi^{2}$ test. PR/VGPR, partial response/very good partial response; CR/nCR, complete response/near CR; G-CSF, granulocyte-colony stimulating factor; B-MNC, blood mononuclear cell; Hb, hemoglobin; Rct, reticulocyte; Plt, platelet.

patients MM who had previously received lenalidomide, underwent $>4$ courses of treatment or had a peripheral blood $\mathrm{Hb}$ level $<100 \mathrm{~g} / \mathrm{l}$ (Fig. 1A). These factors reduced the yield of CD34+ cells, identifying them as negative factors that adversely affect stem cell mobilization and collection. However, multivariate analysis showed that only a low peripheral blood $\mathrm{Hb}$ level was significantly associated with poor mobilization $(\mathrm{P}=0.041$; OR, 1.040; 95\% CI, 1.002-1.080; Table III).
The analysis showed that the factors negatively affecting stem cell mobilization and collection were disease without complete remission, previous chemotherapy beyond the first-line, $>8$ courses chemotherapy treatment, previous treatment with high dose MTX/Ara-c, application of the HyperCVAD-B mobilization scheme, administration of G-CSF for $>5$ days, and collected B-MNC, Hb, Rct and Plt values below $1.9 \times 10^{9} / 1,100 \mathrm{~g} / 1,29 \%$ and $80 \times 10^{9} / 1$, respectively (Table II). The association between these influencing factors 
Table II. Baseline characteristics of patients with lymphoma and the outcome of stem cell mobilization.

\begin{tabular}{|c|c|c|c|c|}
\hline \multirow[b]{2}{*}{ Patient characteristics } & \multirow[b]{2}{*}{ Patients, n (\%) } & \multicolumn{2}{|c|}{ Mobilization, n (\%) } & \multirow[b]{2}{*}{ P-value } \\
\hline & & Success & Failure & \\
\hline Number & 75 (100) & $44(59)$ & $31(41)$ & \\
\hline Age, years $^{\mathrm{a}}$ & $38(16-61)$ & $37.5(17-57)$ & $39(16-61)$ & 0.477 \\
\hline $\begin{array}{l}\operatorname{Sex}^{\mathrm{b}} \\
\text { Male } \\
\text { Female }\end{array}$ & $\begin{array}{l}44(59) \\
31(41)\end{array}$ & $\begin{array}{l}25(57) \\
19(43)\end{array}$ & $\begin{array}{l}19(61) \\
12(39)\end{array}$ & 0.699 \\
\hline 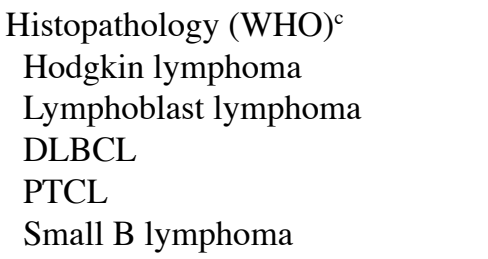 & $\begin{array}{c}7(9) \\
15(20) \\
31(42) \\
15(20) \\
7(9)\end{array}$ & $\begin{array}{c}6(14) \\
5(11) \\
20(45) \\
7(16) \\
6(14)\end{array}$ & $\begin{array}{c}1(3) \\
10(32) \\
11(36) \\
8(26) \\
1(3)\end{array}$ & 0.297 \\
\hline $\begin{array}{l}\text { Status of disease } \\
\text { CR } \\
\text { Not } \mathrm{CR}\end{array}$ & $\begin{array}{l}40(53) \\
35(47)\end{array}$ & $\begin{array}{l}29(66) \\
15(34)\end{array}$ & $\begin{array}{l}11(35) \\
20(65)\end{array}$ & 0.009 \\
\hline $\begin{array}{l}\text { Number of prior treatments lines }{ }^{b} \\
1 \\
\geq 2\end{array}$ & $\begin{array}{l}44(59) \\
31(41)\end{array}$ & $\begin{array}{l}30(68) \\
14(32)\end{array}$ & $\begin{array}{l}14(45) \\
17(55)\end{array}$ & 0.046 \\
\hline $\begin{array}{l}\text { High dose MTX/Ara-c }{ }^{\mathrm{b}} \\
\text { Yes } \\
\text { No }\end{array}$ & $\begin{array}{l}17(23) \\
58(77)\end{array}$ & $\begin{array}{c}6(14) \\
38(86)\end{array}$ & $\begin{array}{l}11(35) \\
20(65)\end{array}$ & 0.026 \\
\hline $\begin{array}{l}\text { Treatment courses } \\
1-8 \\
\geq 9\end{array}$ & $\begin{array}{l}53(71) \\
22(29)\end{array}$ & $\begin{array}{c}36(82) \\
8(18)\end{array}$ & $\begin{array}{l}17(55) \\
14(45)\end{array}$ & 0.012 \\
\hline $\begin{array}{l}\text { Separation times } \\
2 \\
>2\end{array}$ & $\begin{array}{c}71(95) \\
4(5)\end{array}$ & $\begin{array}{c}42(95) \\
2(5)\end{array}$ & $\begin{array}{c}29(94) \\
2(6)\end{array}$ & 1.000 \\
\hline $\begin{array}{l}\text { G-CSF duration }(\mathrm{d})^{\mathrm{b}} \\
1-5 \\
>5\end{array}$ & $\begin{array}{l}60(80) \\
15(20)\end{array}$ & $\begin{array}{c}41(93) \\
3(7)\end{array}$ & $\begin{array}{l}19(61) \\
12(39)\end{array}$ & 0.001 \\
\hline $\begin{array}{l}\text { Hematological values } \\
\text { B-MNC }\left(\times 10^{9} / 1\right)^{\mathrm{a}} \\
\mathrm{Hb}(\mathrm{g} / \mathrm{l})^{\mathrm{a}} \\
\text { Rct }(\%)^{\mathrm{a}} \\
\text { Plt }\left(\times 10^{9} / 1\right)^{\mathrm{a}}\end{array}$ & $\begin{array}{c}1.9(0.1-7.9) \\
98.3(66-135) \\
28.7(19.5-39.9) \\
76.5(19-250)\end{array}$ & $\begin{array}{c}2.4(0.6-7.9) \\
106.8(68-135) \\
31.6(20.7-39.9) \\
109.5(25-250)\end{array}$ & $\begin{array}{c}1.4(0.1-3.0) \\
91.5(66-116) \\
26.8(19.5-34) \\
53(19-176.5)\end{array}$ & $\begin{array}{r}<0.001 \\
<0.001 \\
<0.001 \\
0.001\end{array}$ \\
\hline $\begin{array}{l}\text { Treatment regimes }^{\mathrm{c}} \\
\text { CHOP like } \\
\text { CTX } \\
\text { HyperCVAD part A } \\
\text { HyperCVAD part B } \\
\text { MINE }\end{array}$ & $\begin{array}{l}33(44) \\
17(23) \\
9(12) \\
9(12) \\
7(9)\end{array}$ & $\begin{array}{l}21(47) \\
12(27) \\
3(7) \\
2(5) \\
6(14)\end{array}$ & $\begin{array}{l}12(39) \\
5(16) \\
6(19) \\
7(23) \\
1(3)\end{array}$ & 0.052 \\
\hline
\end{tabular}

${ }^{a}$ Mann-Whitney U test (median value); ${ }^{b} \chi^{2}$ test; test; ${ }^{c}$ Kruskal-Wallis test. DLBCL, diffuse large B-cell lymphoma; PTCL, peripheral T-cell lymphoma; CR, complete response; MTX/Ara-c, methotrexate/cytarabine; G-CSF, granulocyte-colony stimulating factor; B-MNC, blood mononuclear cell; $\mathrm{Hb}$, hemoglobin; Rct, reticulocyte; Plt, platelet; CHOP, cyclophosphamide, epirubicin, vincristine and prednisone; CTX, cyclophosphamide; HyperCVAD part A, treatment with high dose cyclophosphamide, doxorubicin, dexamethasone and vincristine; HyperCVAD part B, treatment with high dose cytosine arabinoside, and methotrexate; MINE, mitoxantraone, ifosfamide and etoposide; WHO, World Health Organization.

and the yield of CD34+ cells is shown in Fig. 1B. Multivariate regression analysis revealed that the disease remission status, usage of MTX/Ara-c, and the Rct value significantly affected the success rate of mobilization and acquisition of CD34+ cells . However, HyperCVAD-B mobilization scheme and Plt value below $80 \times 10^{9} / 1$ were negative affecting factors (Table IV 

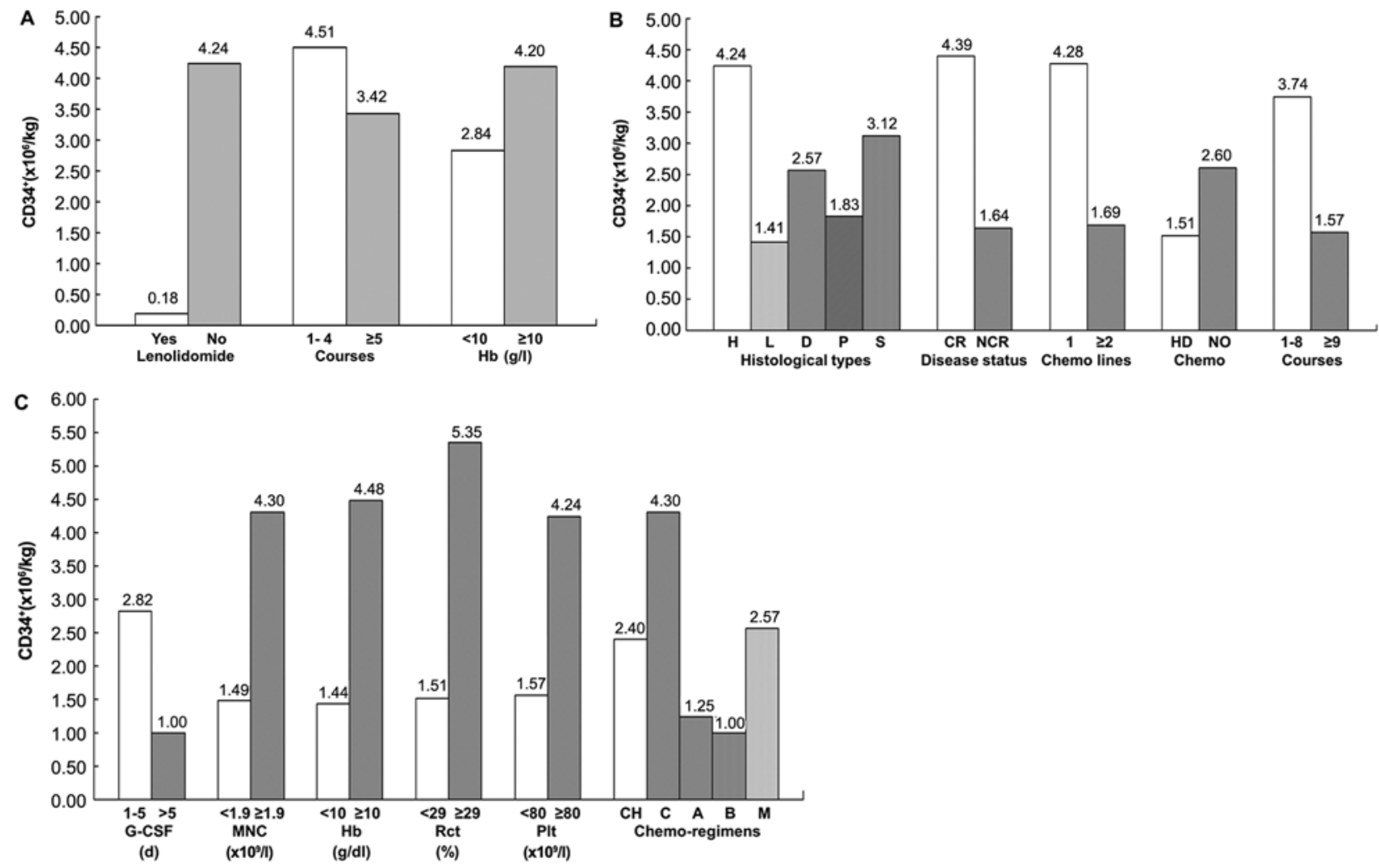

Figure 1. Effect of baseline status on the mobilization of CD34+ cells. (A) Effects of lenalidomide application, chemotherapy course number and hemoglobin level on CD34+ cell mobilization in patients with multiple myeloma. (B) Effects of pathological type, disease status, the number of chemotherapy lines, high dose chemotherapy and chemotherapy course number on CD34+ cell mobilization in patients with lymphoma. (C) Effects of G-CSF administration duration, MNC count, the hemoglobin ( $\mathrm{Hb}$ ) level, hematocrit (Rct: Reticulocyte), platelet (Plt) count and chemotherapy scheme on CD34+ cell mobilization in lymphoma patients. CR, complete response; NCR, near CR; H, Hodgkin's lymphoma; L, Lymphoblast lymphoma; D, Diffuse larger B cell lymphoma; P, Peripheral T-cell lymphoma; S, Small B cell lymphoma; HD, high dose cytosine arabinoside/methotrexate, CH, CHOP regime; C, CTX regime; A, HyperCVAD-A regime; B HyperCVAD-B regime; M, MINE regime.

and Fig. 1C). In 20 of 35 patients (57.1\%) who did not achieve $\mathrm{CR}$, stem cell collection failed. The failure rate of patients who were previously treated with high dose MTX/Ara-c was $64.7 \%$. The failure rates of patients whose Rct was $<29 \%$ or Plt was $<80 \times 10^{9} / 1$, were 61.5 and $57.9 \%$ respectively, and those patients who adopted the HyperCVAD scheme plan A or B were 67.7 (6/9) and 77.8\% (7/9), respectively (data not shown).

Adverse events. The main adverse event in patients was agranulocytosis and the median duration time of neutrophil granulocyte deficiency was 3 days (range, 0-15 days). In 27 patients including $12 \mathrm{MM}$ and 15 lymphoma patients, the deficiency lasted $>5$ days, and in two lymphoma patients the duration was $>10$ days; 13 patients were free from agranulocytosis. Other adverse events included gastrointestinal reactions during chemotherapy, fever due to granulocyte deficiency, hypokalemia, fever associated with G-CSF treatment, and lower limb, waist or back pain, which did not exceed level 2 and were completely resolved following treatment (Table V). No enlargement of the spleen or spleen rupture, and no other serious adverse events were observed.

\section{Discussion}

A key factor in successful ASCT is efficient PBSC acquisition. The general requirement of $\mathrm{CD} 34+$ cell numbers for ensuring successful hematopoietic functional reconstruction is $2.0 \times 10^{6}$ cells $/ \mathrm{kg}$ of patient weight. The acquisition of $5 \times 10^{6}$ cells $/ \mathrm{kg}$ of CD34+ cells is considered to be ideal and this number is sufficient for quick reconstruction of hematopoiesis (7-9). G-CSF has been widely used as a PBSC mobilization stimulator. Early studies found that G-CSF alone could increase PBSCs by 10 to 100 times, with the peak of the drug concentration in plasma occurring on the fifth day (10). G-CSF may interfere with the interaction between stromal cell-derived factor-1 (SDF1) and the CXC chemokine type 4 receptor (CXCR4), and affect the expression of bone marrow stromal cell related adhesion molecules $(11,12)$. Even though its precise mechanism is not well understood, G-CSF treatment resulted in a higher yield of PBSCs, even when hematopoiesis was inhibited during chemotherapy. Therefore G-CSF has been widely used clinically (7-9,13-16); however, no consensus recommendation for the selection of chemotherapy schemes has been established.

In our center, all PBSC mobilization was performed by chemotherapy combined with G-CSF. In accordance with other centers, patients with MM received chemotherapy with high-dose CTX (8,17-19), while patients with lymphoma underwent chemotherapy with various regimens. The present study revealed that adverse events due to treatment were at acceptable levels, but there was a significant difference in the success rates of stem cell mobilization. The combined 
Table III. Univariate and multivariate statistical analysis of factors influencing mobilization in 53 patients with MM.

Successful mobilization

\begin{tabular}{|c|c|c|c|c|c|c|}
\hline \multirow[b]{2}{*}{ Prognostic factors } & \multicolumn{3}{|c|}{ Univariate } & \multicolumn{3}{|c|}{ Multivariate } \\
\hline & P-value & OR & $95 \% \mathrm{CI}$ & P-value & OR & $95 \% \mathrm{CI}$ \\
\hline Without treatment of lenalidomide & 0.027 & 1.400 & $1.005-1.950$ & NS & & \\
\hline Treatment courses $(\leq 4)$ & 0.024 & 3.483 & $0.840-14.449$ & NS & & \\
\hline $\mathrm{Hb}(\geq 100 \mathrm{~g} / \mathrm{l})$ & 0.014 & 2.500 & $0.685-9.121$ & 0.041 & 1.040 & $1.002-1.080$ \\
\hline
\end{tabular}

OR, odds ratio; CI, confidence interval; $\mathrm{Hb}$, hemoglobin; NS, not significant. $\mathrm{P}<0.05$ was considered to indicate a statistically significant difference.

Table IV. Univariate and multivariate statistical analysis of factors influencing mobilization in 75 lymphoma patients.

\begin{tabular}{|c|c|c|c|c|c|c|}
\hline \multirow[b]{3}{*}{ Prognostic factors } & \multicolumn{6}{|c|}{ Successful mobilization } \\
\hline & \multicolumn{3}{|c|}{ Univariate } & \multicolumn{3}{|c|}{ Multivariate } \\
\hline & P-value & OR & $95 \% \mathrm{CI}$ & P-value & OR & $95 \% \mathrm{CI}$ \\
\hline Histopathology (WHO) & 0.049 & - & - & NS & & \\
\hline Disease status (Not CR) & 0.002 & 0.284 & $0.108-0.746$ & 0.024 & 0.212 & $0.055-0.813$ \\
\hline Number of prior lines (1) & 0.014 & 2.602 & $1.006-6.729$ & NS & & \\
\hline G-CSF administration duration (1-5 d) & 0.010 & 8.632 & $2.178-34.211$ & NS & & \\
\hline High dose MTX/Ara-c (none) & 0.003 & 0.287 & $0.093-0.891$ & 0.045 & 0.197 & $0.040-0.963$ \\
\hline Treatment courses $(1-8)$ & 0.021 & 3.706 & $1.306-10.513$ & NS & & \\
\hline HyperCVAD-B mobilization scheme & 0.029 & - & - & 0.030 & 1.975 & $1.070-3.646$ \\
\hline $\mathrm{B}-\mathrm{MNC} \geq 1.9$ & $<0.001$ & 4.500 & $1.681-12.046$ & NS & & \\
\hline $\mathrm{Hb} \geq 100$ & $<0.001$ & 5.558 & $2.009-15.379$ & NS & & \\
\hline $\operatorname{Rct}(\geq 29 \%)$ & $<0.001$ & 8.176 & $2.826-23.650$ & 0.008 & 1.229 & $1.056-1.431$ \\
\hline Plt $\geq 80 \times 10^{9} / 1$ & $<0.001$ & 4.278 & $1.591-11.505$ & 0.032 & 1.017 & $1.001-1.034$ \\
\hline
\end{tabular}

OR, odds ratio; CI, confidence interval; WHO, World Health Organization; Not CR, not complete response; G-CSF, granulocyte-colony stimulating factor; MTX/Ara-c, Ara-c methotrexate/cytarabine; B-MNC, mean value of peripheral blood mononuclear cells; Hb, hemoglobin; Rct, reticulocyte; Plt, platelet; NS, not significant; $\mathrm{P}<0.05$ was considered to indicate a statistically significant difference.

success rate of CTX, CHOP and MINE therapeutic schemes was $68.4 \%$, while that of HyperCVAD scheme plans A or B was only $27.8 \%$, suggesting that HyperCVAD might not be a suitable treatment option for patients with lymphoma. Other studies recommended various schemes with a success rate $>70 \%$, which included high-dose CTX, intermediate dose cytarabine, cytarabine combined with etoposide, ESHAP/DSHAP and ICE/RICE (8,20-23).

In the present study, the overall mobilization failure rate was $35.2 \%$ (45 of 128 patients), the failure rate of MM patients was $26.4 \%$ (14 of 53 patients) and that of lymphoma patients was $41 \%$ ( 31 of 75 patients). The mobilization failure rate appeared to be relatively higher than previously reported rates of 5-30\% (8,18,19,21-26). The reasons for this discrepancy are unknown; however, some invariable or variable factors might have played a role, such as mobilization timing, mobilization schemes, and various parameters set by the separator. Further investigation is required to elucidate whether altering these factors could optimize PBSC mobilization in lymphoma, as well as in MM patients. Lymphoma and MM share the same malignant tumor cell origin and their therapeutic strategies are similar. However, in the present study the failure rate of lymphoma patient treatment was two times greater than that of MM patients. It has been reported that in NHL and HL, both G-CSF mobilization alone and G-CSF combined with chemotherapy resulted in similar failure rates, and these rates were four times greater than those of MM $(8,9)$. It may be that previous high-dose chemotherapy in lymphoma patients affected stem cell mobilization and collection. In MM patients, treatment with multiple courses of lenalidomide (27), high-dose chemotherapy, administration of purine analogues, and 1-3 lines of chemotherapy were reported to be adverse factors for mobilization $(21,25)$. In accordance with this, lenalidomide treatment, multiple courses of chemotherapy, incomplete alleviation of disease, large-doses of cytarabine or MTX, and previous chemotherapy of more than 2 lines, were 
Table V. Adverse events.

\begin{tabular}{|c|c|c|c|c|}
\hline Adverse events, n (\%) & Total $(n=128)$ & Multiple myeloma $(n=53)$ & Lymphoma $(\mathrm{n}=75)$ & P-value \\
\hline \multicolumn{5}{|c|}{ Hematologic events (3/4 grade) } \\
\hline Neutropenia $^{\mathrm{a}}$ & $115(89.8)$ & $49(92.5)$ & $66(88.0)$ & 0.850 \\
\hline Thrombocytopenia $^{a}$ & $40(31.3)$ & $14(26.4)$ & $26(34.7)$ & 0.470 \\
\hline Anemia $^{\mathrm{a}}$ & $12(9.4)$ & $3(5.7)$ & $9(12.0)$ & 0.267 \\
\hline \multicolumn{5}{|c|}{ Non-hematological events (all grades) } \\
\hline Nausea and vomiting ${ }^{\mathrm{a}}$ & $59(46.1)$ & $28(52.8)$ & $31(41.3)$ & 0.438 \\
\hline Infection $^{\mathrm{a}}$ & $66(51.6)$ & $25(47.2)$ & $41(54.7)$ & 0.635 \\
\hline Fatigue $^{\mathrm{a}}$ & $21(16.4)$ & $6(11.3)$ & $15(20.0)$ & 0.265 \\
\hline Kaliopenia $^{\mathrm{a}}$ & $21(16.4)$ & $9(17.0)$ & $12(16.0)$ & 0.901 \\
\hline Diarrhea $^{\mathrm{a}}$ & $9(7.0)$ & $3(5.7)$ & $6(8.0)$ & 0.634 \\
\hline GPT elevation $^{\mathrm{a}}$ & $5(3.9)$ & $2(3.8)$ & $3(4.0)$ & 0.950 \\
\hline Osteodynia & $2(1.6)$ & $1(1.9)$ & $1(1.3)$ & 0.807 \\
\hline $\operatorname{Rash}^{\mathrm{a}}$ & $3(2.3)$ & $1(1.9)$ & $2(2.7)$ & 0.779 \\
\hline Coagulation function ${ }^{\mathrm{a}}$ & $1(0.8)$ & 0 & $1(1.3)$ & 0.402 \\
\hline
\end{tabular}

${ }^{\mathrm{a}} \chi^{2}$ test.

found to be unfavorable factors for successful mobilization in MM patients. These factors may have negatively affected patient's bone marrow function, and more effective mobilization strategies should be considered.

Additionally, the efficiency of stem cell collection after the second round of mobilization was evaluated; three of 45 patients who failed the first round of mobilization underwent a second round. However, the yield of CD34+ cells was insufficient, which confirmed the general concept that if the first mobilization failed, despite the type of disease and mobilization scheme, the success rate of a second mobilization was also low $(8,23,25,28)$. Therefore, it should be emphasized that the optimal yield of CD34+ cells is achieved following the first mobilization. However, several randomized clinical trials have suggested that a new mobilization agent, plerixafor, which inhibits the binding of chemokine SDF-1 to its receptor CXCR4, is ideal for the mobilization of PBSCs, either used alone or in combination with G-CSF $(13,14,17,18,24,26,29-32)$. Plerixafor successfully mobilized PBSCs even in patients who received high-doses of chemotherapy or who failed the first mobilization (14,17,30-32). However, it is not widely used in Chinese clinical practice.

It has been reported that specific parameters prior to PBSC collection, such as the duration time of G-CSF administration and B-MNC, Plt and CD34+ cell counts, may predict mobilization success $(15,23,25,26,33,34)$. However, when used alone, none of these factors were able to predict mobilization outcome. The present study revealed that a higher hemoglobin level was a significant factor for successful mobilization both in MM and lymphoma patients. Conversely, a G-CSF administration time $>5$ days, and lower numbers of B-MNC and Plt were associated with mobilization failure in lymphoma, but not MM patients. Regardless of the disease and the mobilization scheme applied, the peripheral blood CD34+ cell count measured between mobilization and collection have been reported to correlate with the first day acquisition rate. Hence, the peripheral blood CD34+ cell count appears to be the only factor that could be used to determine the optimal timing of PBSC collection $(8,16,23,25)$. However, due to the retrospective nature of the present study, data on these CD34+ cell counts were unavailable.

In summary, the present study revealed that chemotherapy combined with G-CSF in MM and lymphoma patients yielded CD34+ cells; however, the failure rate was relatively high. Multivariate analyses revealed that $\mathrm{Hb}$ values $<100 \mathrm{~g} / \mathrm{l}$ in MM patients who did not achieve CR, high dose MTX/Ara-c medication, HyperCVAD-B mobilization scheme, as well as low Rct $(\leq 29 \%)$ and Plt counts $\left(\leq 80 \times 10^{9} / 1\right)$ in lymphoma patients were significant factors for insufficient PBSC mobilization. It is anticipated that the introduction of the mobilization agent plerixafor to the scheme may increase the success rate of mobilization in patients with poor bone marrow function. Therefore, it is important to further investigate the factors associated with successful stem cell mobilization and collection for the establishment of a more efficient and cost-effective ideal protocol, especially for patients with a high risk of failure. However, since the study was limited to a relatively small number of patients, a prospective study with a larger cohort will be required for further confirmation of these findings.

\section{Acknowledgements}

Not applicable.

\section{Funding}

The present study was supported by the National Natural Science Foundation of China (grant no. 81471532), the National Science and Technology Support Program (grant no. 2014BAI09B12) and the Natural Science Foundation of Zhejiang Province (grant no. LY16H080001). 


\section{Availability of data and material}

The datasets used and/or analyzed during the current study are available from the corresponding author on reasonable request.

\section{Authors' contributions}

GZ, JH, ZC and DH were responsible for the conception and design of the study. All authors were responsible for the data acquisition and analysis. GZ was responsible for statistical analysis. GZ drafted the manuscript. GZ and JH revised and commented on the draft. YL, JS, GW, JS and WZ were responsible for primary data collection. All authors read and approved the final version of the manuscript.

\section{Ethics approval and consent to participate}

The present study was approved by the ethical committee of the Bone Marrow Transplantation Center of the First Affiliated Hospital, Zhejiang University, and all participants signed informed consent forms.

\section{Patient consent for publication}

Not applicable.

\section{Competing interests}

The authors declare that they have no competing interests.

\section{References}

1. Hamadani M: Autologous hematopoietic cell transplantation: An update for clinicians. Ann Med 46: 619-632, 2014.

2. Vincent Rajkumar S: Multiple myeloma: 2014 Update on diagnosis, risk-stratification, and management. Am J Hematol 89: 999-1009, 2014.

3. Hubel K, de la Rubia J, Azar N and Corradini P: Current status of haematopoietic autologous stem cell transplantation in lymphoid malignancies: A european perspective. Eur J Haematol 94: 12-22, 2015.

4. Swerdlow SH, Campo E, Harris NL, Jaffe ES, Pileri SA, Stein H and Thiele J: WHO classification of tumours of haematopoietic and lymphoid tissues. Lyon, France: IARC Press, 2008.

5. Gasová Z, Marinov I, Hrubá A, Benesová K and Turek P: The efficiency of PBPC collections and the relationship to the precollection concentration of CD 34+ cells in blood. Transfus Sci 20: 181-188, 1999.

6. Pozotrigo M, Adel N, Landau H, Lesokhin A, Lendvai N, Chung DJ, Chimento D, Riedel E, Chen X, Reich L, et al: Factors impacting stem cell mobilization failure rate and efficiency in multiple myeloma in the era of novel therapies: Experience at memorial sloan kettering cancer center. Bone Marrow Transplant 48: 1033-1039, 2013.

7. Hoggatt J, Speth JM and Pelus LM: Concise review: Sowing the seeds of a fruitful harvest: Hematopoietic stem cell mobilization. Stem cells 31: 2599-2606, 2013.

8. Pusic I, Jiang SY, Landua S, Uy GL, Rettig MP, Cashen AF, Westervelt P, Vij R, Abboud CN, Stockerl-Goldstein KE, et al: Impact of mobilization and remobilization strategies on achieving sufficient stem cell yields for autologous transplantation. Biol Blood Marrow Transplant 14: 1045-1056, 2008.

9. Gertz MA, Wolf RC, Micallef IN and Gastineau DA: Clinical impact and resource utilization after stem cell mobilization failure in patients with multiple myeloma and lymphoma. Bone Marrow Transplant 45: 1396-1403, 2010.

10. Dreger P, Haferlach T, Eckstein V, Jacobs S, Suttorp M, Löffler H, Müller-Ruchholtz W and Schmitz N: G-CSF-mobilized peripheral blood progenitor cells for allogeneic transplantation: Safety, kinetics of mobilization, and composition of the graft. Br J Haematol 87: 609-613, 1994.
11. Petit I, Szyper-Kravitz M, Nagler A, Lahav M, Peled A, Habler L, Ponomaryov T, Taichman RS, Arenzana-Seisdedos F, Fujii N, et al: G-CSF induces stem cell mobilization by decreasing bone marrow SDF-1 and up-regulating CXCR4. Nat Immunol 3: 687-694, 2002. 12. Salvucci O, Jiang K, Gasperini P, Maric D, Zhu J, Sakakibara S, Espigol-Frigole G, Wang S and Tosato G: MicroRNA126 contributes to granulocyte colony-stimulating factor-induced hematopoietic progenitor cell mobilization by reducing the expression of vascular cell adhesion molecule 1. Haematologica 97: 818-826, 2012.

13. Shaughnessy P, Uberti J, Devine S, Maziarz RT, Vose J, Micallef I, Jacobsen E, McCarty J, Stiff P, Artz A, et al: Plerixafor and G-CSF for autologous stem cell mobilization in patients with NHL, Hodgkin's lymphoma and multiple myeloma: Results from the expanded access program. Bone Marrow Transplant 48: 777-781, 2013.

14. Abhyankar S, DeJarnette S, Aljitawi O, Ganguly S, Merkel D and McGuirk J: A risk-based approach to optimize autologous hematopoietic stem cell (HSC) collection with the use of plerixafor. Bone Marrow Transplant 47: 483-487, 2012.

15. Sugrue MW, Williams K, Pollock BH, Khan S, Peracha S, Wingard JR and Moreb JS: Characterization and outcome of 'hard to mobilize' lymphoma patients undergoing autologous stem cell transplantation. Leuk Lymphoma 39: 509-519, 2000.

16. Rossi G, Skert C, Morello E, Almici C, Arcaini L, Basilico C, Cavalli L, Botto B, Castelli A, Pica G, et al: PBSC mobilization in lymphoma patients: Analysis of risk factors for collection failure and development of a predictive score based on the kinetics of circulating CD34+ cells and WBC after chemotherapy and G-CSF mobilization. Hematol Oncol 33: 125-132, 2015.

17. Cooper DL, Medoff E, Patel N, Baker J, Pratt K, Foss F, Seropian SE, Perreault S and Wu Y: Autologous stem cell mobilization in the age of plerixafor. Clin Lymphoma Myeloma Leuk 16: 411-416, 2016.

18. Teusink A, Vinks A, Zhang K, Davies S, Fukuda T, Lane A, Nortman S, Kissell D, Dell S, Filipovich A and Mehta P: Genotype-directed dosing leads to optimized voriconazole levels in pediatric patients receiving hematopoietic stem cell transplantation. Biol Blood Marrow Transplant 22: 482-486, 2016.

19. Tuchman SA, Bacon WA, Huang LW, Long G, Rizzieri D, Horwitz M, Chute JP, Sullivan K, Morris Engemann A, Yopp A, et al: Cyclophosphamide-based hematopoietic stem cell mobilization before autologous stem cell transplantation in newly diagnosed multiple myeloma. J Clin Apher 30: 176-182, 2015.

20. Calderon-Cabrera C, Carmona Gonzalez M, Martin J, Ríos Herranz E, Noguerol P, De la Cruz F, Carrillo E, Falantes JF, Parody R, Espigado I, et al: Intermediate doses of cytarabine plus granulocyte-colony-stimulating factor as an effective and safe regimen for hematopoietic stem cell collection in lymphoma patients with prior mobilization failure. Transfusion 55: 875-879, 2015.

21. Xia W, Ma CK, Reid C, Bai L, Wong K, Kerridge I, Ward C and Greenwood M: Factors determining pbsc mobilization efficiency and nonmobilization following ICE with or without rituximab (R-ICE) salvage therapy for refractory or relapsed lymphoma prior to autologous transplantation. J Clin Apher 29: 322-330, 2014.

22. Ozkan HA, Bal C and Gulbas Z: Chemomobilization with high-dose etoposide and G-CSF results in effective and safe stem cell collection in heavily pretreated lymphoma patients: Report from a single institution study and review. Eu J Haematol 92: 390-397, 2014.

23. Re A, Cattaneo C, Skert C, Balsalobre P, Michieli M, Bower M, Ferreri AJ, Hentrich M, Ribera JM, Allione B, et al: Stem cell mobilization in HIV seropositive patients with lymphoma. Haematologica 98: 1762-1768, 2013.

24. Clark RE, Bell J, Clark JO, Braithwaite B, Vithanarachchi U, McGinnity N, Callaghan T, Francis S and Salim R: Plerixafor is superior to conventional chemotherapy for first-line stem cell mobilisation, and is effective even in heavily pretreated patients. Blood Cancer J 4: e255, 2014.

25. Sancho JM, Morgades M, Grifols JR, Juncà J, Guardia R, Vives S, Ferrà C, Batlle M, Ester A, Gallardo D, et al: Predictive factors for poor peripheral blood stem cell mobilization and peak CD34(+) cell count to guide pre-emptive or immediate rescue mobilization. Cytotherapy 14: 823-829, 2012.

26. Lee KH, Jung SK, Kim SJ, Jang JH, Kim K, Kim WS, Jung CW, Kim DW and Kang ES: Incidence and risk factors of poor mobilization in adult autologous peripheral blood stem cell transplantation: A single-centre experience. Vox Sang 107: 407-415, 2014. 
27. Kumar S, Dispenzieri A, Lacy MQ, Hayman SR, Buadi FK Gastineau DA, Litzow MR, Fonseca R, Roy V, Rajkumar SV and Gertz MA: Impact of lenalidomide therapy on stem cell mobilization and engraftment post-peripheral blood stem cell transplantation in patients with newly diagnosed myeloma. Leukemia 21: 2035-2042, 2007.

28. Watts MJ, Ings SJ, Flynn M, Dodds D, Goldstone AH and Linch DC: Remobilization of patients who fail to achieve minimal progenitor thresholds at the first attempt is clinically worthwhile. Br J Haematol 111: 287-291, 2000.

29. RussellN,Douglas K,Ho AD,Mohty M,CarlsonK,OssenkoppeleGJ, Milone G, Pareja MO, Shaheen D, Willemsen A, et al: Plerixafor and granulocyte colony-stimulating factor for first-line steady-state autologous peripheral blood stem cell mobilization in lymphoma and multiple myeloma: Results of the prospective PREDICT trial. Haematologica 98: 172-178, 2013.

30. Duarte RF, Shaw BE, Marin P, Kottaridis P, Ortiz M, Morante C, Delgado J, Gayoso J, Goterriz R, Martínez-Chamorro C, et al: Plerixafor plus granulocyte CSF can mobilize hematopoietic stem cells from multiple myeloma and lymphoma patients failing previous mobilization attempts: EU compassionate use data. Bone Marrow Transplant 46: 52-58, 2011.
31. Arcaini L, Laszlo D, Rizzi S, Balzarotti M, Antoniazzi F, Zilioli VR, Guggiari E, Farina L, Todisco E, Bonfichi M, et al: Plerixafor and G-CSF for PBSC mobilization in patients with lymphoma who failed previous attempts with G-CSF and chemotherapy: A REL (Rete Ematologica Lombarda) experience. Leukemia Res 35: 712-714, 2011.

32. Keating GM: Plerixafor: A review of its use in stem-cell mobilization in patients with lymphoma or multiple myeloma. Drugs 71: 1623-1647, 2011.

33. Ikeda K, Kozuka T and Harada M: Factors for PBPC collection efficiency and collection predictors. Transfus Apher Sci 31: 245-259, 2004.

34. Perea G, Sureda A, Martino R, Altés A, Martínez C, Cabezudo E, Amill B, Martín-Henao GA, González Y, Muñoz L, et al: Predictive factors for a successful mobilization of peripheral blood CD34+ cells in multiple myeloma. Annals Hematol 80: 592-597, 2001. 